\title{
Application of Manure and Phosphorus Bio-Solubilizers with Rock Phosphate in Calcareous Soils to Increase Phosphorus Availability and Productivity of Safflower Plant
}

\author{
Attia, M. F., Hassan ${ }^{1}$, A. Fawy ${ }^{1}$, Rehab H. Hegab ${ }^{1}$ and Noha M.M. ${ }^{1}$
}

\begin{abstract}
Field experiments were carried out in Ras Sudr Research Station $\left(29^{\circ} 32^{\prime} 29^{\prime \prime} \mathrm{N}\right.$ and $32^{\circ} 39^{\prime} 2^{\prime \prime}$ E) during two successive seasons of 2013 and 2014. Salinity of irrigation water was $7.36 \mathrm{dSm}^{-1}$ and that of soil paste extract was $7.96 \mathrm{dSm}^{-1}$. The experimental design was a randomized complete block, with 3 replicates. The treatments included 4 factors as follows: Factor 1: Farmyard manure, 2: treatments, FYM 1 and FYM 2 of 24 and $48 \mathrm{~m}^{3}$ farmyard manure per hectare, respectively. Factor 2: $P$ is two types, RP "rock phosphate $(9.5 \%$ $\left.\mathrm{P}_{2} \mathrm{O}_{5}\right)$ ")and SP "superphosphate $\left(\mathbf{1 5 . 5 \%} \mathbf{P}_{2} \mathrm{O}_{5}\right)$ " Factor 3: $\mathrm{P}$ applied at 2 rates of 31 and $62 \mathrm{~kg} \mathrm{P} \mathrm{ha}^{-1}$, respectively. Factor 4: Biofertilizers applied at 4 treatments as follows: none, VAM (Vesicular-arbuscular mycorrhiza), PS "Psolubilizing bacteria" (Pseudomonas fluorescence and Bacillus megaterium) and VAM+PS. Thus, the total number of treatments in combinations were 32 ( 2 FYM, 2 P-type, $2 \mathrm{P}$ rates and 4 biofertilzations). An extra treatment was performed involving no application of fertilizers nor biofertilizers (control). The biofertilizer was a mixture of inoculate of the P-solubilizing bacteria of Pseudomonas fluorescence and Bacillus megaterium. VAM was added at $20 \mathrm{~kg} \mathrm{ha}^{-1}$. The results showed that plant yield and $N, P$ and $K$ contents and uptake increased by applying bio-fertilizers as well as farmyard manure and $\mathbf{p -}$ mineral fertilizers. The most effective combinations are as follows: RP2 + (VAM) +FYM1 < SP2 + VAM + FYM1 < SP2 + (PS)+FYM1 < SP2 + (VAM +PS) + FYM1 $<$ SP2 + $(\mathrm{VAM}+\mathrm{PS})+$ FYM2. The Integration between mineral and bio-P-fertilizers with farmyard manure (FYM) application produced the most effective treatment (SP2+ VAM +PS+FYM2) which achieved the highest safflower yields which recorded 6.59, 3.36 and 36 for stalk (ton ha ${ }^{-1}$ ), seeds (ton ha ${ }^{-1}$ ) and oil (\%) respectively.
\end{abstract}

Keywords: Rock phosphate, Superphosphate, Bio-Pfertilizers, farmyard manure, safflower, sandy loam soil Ras Sudr

\section{INTRODUCTION}

Negative effect of salinity for agricultural activities is common in the newly reclamation areas of SinaiEgypt, especially in soils with high salinity water irrigation of Ras Sudr regions. Ras Sudr soils are affected by irrigation with saline water, which increased soil salinity (Hergert and Knudsen 2004). They reported that the water of $\mathrm{EC}<0.75 \mathrm{dSm}^{-1}$ has no detrimental effect, $0.75-1.50 \mathrm{dSm}^{-1}$ has detrimental effects on sensitive crops, $1.50-3.0 \mathrm{dSm}^{-1}$ required careful management practices, and 3.0-7.5 $\mathrm{dSm}^{-1}$ was used only for salt tolerant plants. Safflower (Carthamus Tinctorius L.) is a herbaceous plant cultivated for its seed oil, and is grown in soils of arid regions which included many saline soils, since it is moderately tolerant to salinity (Oelke et al., 1992). Application of antioxidants can alleviate the adverse effect of salinity (Farouk, 2011). Phosphorus could be involved in such alleviation and presence of enough $\mathrm{P}$ in the rhizosphere can augment plant resistance to salinity (Ceulemans et al., 2011 and Lambers et al., 2014).

Concerning to farmyard manure and mineral $\mathrm{P}$ fertilizer on yield components and nutrients content in safflower plants; Kizil et al., (2008) stated that the seed yield and fatty oil percentage of the stalk cultivars ranged from 1706 to $3111 \mathrm{~kg} \mathrm{ha}^{-1}$ and 26.1 to $35.1 \%$, respectively. Rabie et al., (2010) reported that the combination of high concentration of compost (20 ton/fed) and rock phosphate (1000 kg/fed) recorded the highest values of yield parameters and good quality of safflower oil by increasing unsaturated / saturated fatty acids ratio. Ali and Mahmoud (2012) stated that the highest yield components and nutrient uptake were obtained when safflower was fertilized by 18 ton farmyard manure along with $130 \mathrm{~kg} \mathrm{~N} \mathrm{ha}^{-1}$. Ghasemi et al. (2012) obtained highest seed yield of safflower (3512 $\mathrm{kg} \mathrm{ha}^{-1}$ ) by application of biofertilizers and mineral fertilizers. Raju et al. (2013) applied $50 \%$ of recommended $\mathrm{N}$ as inorganic forms and $50 \%$ as organic form to safflower and obtained the highest seed yield and N, P and K uptake. Hamza (2015) obtained the highest seed yield and oil yield of 2890 and $927 \mathrm{~kg} \mathrm{ha}^{-1}$ with plant density of 240000 plant ha ${ }^{-1}$.

Regarding to the $\mathrm{P}$ bio-fertilizer effect on the yield parameters and nutrients contents; Yasin et al., (2012) stated that P-biofertilization is important for safflower. Neetu et al. (2012) obtained maximum yield by inoculating plants with Arbuscular Mycorrhizal Fungi (AMF) i.e. Vesicular-arbuscular mycorrhiza "VAM" and Pseudomonas fluorescens. They also reported that inoculation with Azotobactor and Azosprillum to fix atmospheric nitrogen had positive effects. El Mokadem and Sorour (2014) reported that Azospirillum $+\mathrm{P}$

${ }^{1}$ Soil Fertility and Microbiology Dept.,

Desert Research Center (DRC), Cairo

Received December 14, 2016, Accepted December 29, 2016 
dissolving bacteria + foliar spray of nutrients produced the highest growth and yield parameters. Amin and Moayedi (2014) reported that the combination of using mineral $\mathrm{N}$ and $\mathrm{P}$ with $\mathrm{P}$ Bio-fertilizers increased growth parameters and yield of safflower. The objective of the current work therefore, was to evaluate the effect of farmyard manure, mineral phosphorus and P-biosolubilizes on the growth performance of safflower under conditions of salinity at Ras Sudr-Sinai, Egypt.

\section{MATERIALS AND METHODS}

Field experiment was carried out in Ras Sudr Research Sation (located at 29 32' 29" N and 32 39' 27 " E) of Desert Research Center during two successive seasons (2013 and 2014). The salinity of irrigation water was $7.36 \mathrm{dSm}^{-1}$ and salinity of soil paste extract was $7.96 \mathrm{dSm}^{-1}$ (Tables, 1 and 2). Seeds of safflower (Carthamus Tinctorius L.) cv Giza 1 were sown on $15^{\text {th }}$ of November 2013, $20 \mathrm{~cm}$ between seeds and $70 \mathrm{~cm}$ between rows at about $3 \mathrm{~cm}$ depth. Final plant density was 71400 plants ha $^{-1}$ (30000 plant Egyptian feddan $\left.{ }^{-1}\right)$.

Available $\mathrm{P}$ was determined according to Olsen el al., (1982). Available potassium was extracted by ammonium acetate. Available nitrogen was extracted by potassium chloride and determined by Kjeldahl method. Available micronutrients were extracted by DTPA and measured by Atomic Absorption Spectrometry. Soil physical and chemical analyses were determined according to the methods of Page et al. (1982) and Klute (1986) and the results obtained are shown in Table 1 and 2. The experimental design was a randomized complete block with 3 replicates. There were 3 factors as follows; Factor 1: Farmyard manure; 2 treatments, $\mathrm{FYM}_{1}$ and $\mathrm{FYM}_{2}$ of 24 and $48 \mathrm{~m}^{3}$ farmyard manure per hectare, respectively, Factor 2: two types of $\mathrm{P}$, RP "rock phosphate $\left(9.5 \% \quad \mathrm{P}_{2} \mathrm{O}_{5}\right)$ " and SP "superphosphate $\left(15.5 \% \mathrm{P}_{2} \mathrm{O}_{5}\right)$ ", Factor 3: P applied at 2 rates of 31 and $62 \mathrm{~kg} \mathrm{P} \mathrm{ha-1,} \mathrm{respectively,} \mathrm{Factor} \mathrm{4:}$ Biofertilizers applied at 4 treatments as following; none, VAM (Vesicular-arbuscular mycorrhiza), PS "Psolubilizing bacteria" (Pseudomonas fluorescence and Bacillus megaterium) and VAM+PS. Thus, the total treatments combinations were 32 (2 FYM, 2 P-type, 2 P rates and 4 biofertilizers). An extra treatment was performed involving no application of fertilizers nor biofertilizers (non-treated). The biofertilizer was a mixture of inoculates of the P-solubilizing bacteria of Pseudomonas fluorescence and Bacillus megaterium which added at one rate of $2 \mathrm{~L} / 200 \mathrm{~L}$. VAM was added at a rate of $20 \mathrm{~kg} \mathrm{ha}^{-1}$. All treatments received $170 \mathrm{~kg} \mathrm{~N}$ $\mathrm{ha}^{-1}$ (as urea: $460 \mathrm{~g} \mathrm{~N} \mathrm{~kg}^{-1}$ ) $+100 \mathrm{~kg} \mathrm{~K} \mathrm{ha}^{-1}$ (as KSulphate: $480 \mathrm{~g} \mathrm{~K}_{2} \mathrm{O} \mathrm{kg}^{-1}$ ), in 3 equal splits $40,80,120$ days after seeding.

Isolates of bacteria used as bio-fertilizers were purified and identified according to (Bergey's Manual of Determinative Bacteriology, 1994). The selected isolates of $B$. megaterium and $P$. fluorescence were subjected to different biochemical tests for screening their hormonal and enzymatic activity (Rizzolo et al. 1993). They produce biochemical and hormonal substances (Table 4) that could result in beneficial effects in the field (El-Saidy et al., 2011).

Table 1. Chemical and physical properties of the experimental soil

\begin{tabular}{|c|c|c|c|c|c|c|c|c|c|}
\hline \multirow{3}{*}{$\begin{array}{l}\text { Depth } \\
\text { (cm) }\end{array}$} & \multirow{3}{*}{$\mathbf{p H}$} & \multirow{3}{*}{$\begin{array}{c}\text { E.C } \\
\left(\mathrm{dSm}^{-1}\right)\end{array}$} & & & Partic & ize distri & ution & \multirow{3}{*}{ Texture } & \multirow{3}{*}{$\begin{array}{c}\text { C.E.C } \\
\left(\mathrm{cmol} \mathrm{kg}^{-1}\right)\end{array}$} \\
\hline & & & $\mathbf{O M}$ & $\mathrm{CaCO}_{3}$ & Sand & Silt & Clay & & \\
\hline & & & \multicolumn{2}{|c|}{$\%$} & \multicolumn{3}{|c|}{$\%$} & & \\
\hline $0-30$ & 7.87 & 7.96 & 2.28 & 27.2 & 79.5 & 9.72 & 10.78 & L.S. & 6.18 \\
\hline $30-60$ & 7.65 & 7.58 & 1.82 & 28.3 & 78.26 & 11.35 & 10.39 & L.S. & 6.96 \\
\hline \multicolumn{10}{|c|}{ Soluble cations and anions in soil $\left(\mathrm{mmol} \mathrm{L}^{-1}\right)$} \\
\hline & $\mathrm{Na}$ & & & $\mathrm{Ca}$ & $\mathrm{Mg}$ & $\mathrm{HCO}_{3}$ & & $\mathrm{Cl}^{-}$ & $\mathrm{SO}_{4}^{2-}$ \\
\hline $0-30$ & 43.6 & & & 22.3 & 5.2 & 8.3 & & 48.2 & 23.1 \\
\hline $30-60$ & 40.5 & & & 15.4 & 4.1 & 3.8 & & 45.3 & 23.4 \\
\hline \multicolumn{10}{|c|}{ Available nutrients in soil $\left(\mathrm{mg} \mathrm{kg}^{-1}\right)$} \\
\hline & $\mathrm{N}$ & & & $\mathrm{K}$ & $\mathrm{Fe}$ & $\mathrm{Mn}$ & & $\mathrm{Zn}$ & $\mathrm{Cu}$ \\
\hline $0-30$ & 38.5 & & & 51.3 & 4.32 & 2.23 & & 1.36 & 0.64 \\
\hline $30-60$ & 23.8 & & & 57.5 & 4.73 & 2.39 & & 1.42 & 0.69 \\
\hline
\end{tabular}

Table 2. The main chemical composite of groundwater of irrigation $\left(\mathrm{mmol} \mathrm{L}^{-1}\right)$

\begin{tabular}{ccccccccc}
$\mathrm{pH}$ & $\mathrm{EC}$ & $\mathrm{Na}$ & $\mathrm{K}$ & $\mathrm{Ca}$ & $\mathrm{Mg}$ & $\mathrm{HCO}_{3}^{-}$ & $\mathrm{Cl}^{-}$ & $\mathrm{SO}_{4}{ }^{2-}$ \\
7.87 & 7.36 & 43.9 & 2.6 & 19.5 & 7.6 & 6.7 & 44.3 & 22.6 \\
\hline
\end{tabular}


Table 3. Fertilizers treatments during the two seasons

\begin{tabular}{|c|c|c|c|c|}
\hline \multirow{3}{*}{$\begin{array}{l}\text { Fertilizer } \\
\text { Treatment }\end{array}$} & \multicolumn{4}{|c|}{ Mineral fertilizer } \\
\hline & \multicolumn{2}{|c|}{ Superphosphate } & \multicolumn{2}{|c|}{ Rock phosphate } \\
\hline & kg $P h^{-1}$ & kg SP ha ${ }^{-1}$ & kg P ha ${ }^{-1}$ & kg RP ha \\
\hline Phosphorus 1 & 31 & 461 & 31 & 752 \\
\hline Phosphorus 2 & 62 & 921 & 62 & 1504 \\
\hline $\mathrm{N} \& \mathrm{~K}_{2} \mathrm{O}$ & \multicolumn{4}{|c|}{167 and $100 \mathrm{~kg} \mathrm{ha}^{-1}$ of $\mathrm{N}$ and $\mathrm{K}$ respectively(applied for all plots) } \\
\hline FYM & \multicolumn{4}{|c|}{24 and $48 \mathrm{~m}^{3} \mathrm{ha}^{-1}$ added during seeds bed time } \\
\hline Bio-fertilizer 1 & \multirow{2}{*}{\multicolumn{4}{|c|}{$\begin{array}{l}\text { P solubilizing bacteria (PSB), B. megaterium \& } P \text {. fluorescence applied at } 2 \mathrm{~L} / 200 \mathrm{~L} \\
*(\mathrm{VAM}) \text { fungi }\left(19 \mathrm{~kg} \mathrm{~h}^{-1}\right) \text { added to soil at the time of } \mathrm{P} \text { applied. }\end{array}$}} \\
\hline Bio-fertilizer 2 & & & & \\
\hline
\end{tabular}

Table 4. The biochemical activities of microbial isolates (according to Rizzolo et al. 1993)

\begin{tabular}{lcc}
\hline $\begin{array}{l}\text { Excreted hormone } \\
\left(\boldsymbol{\mu g} \mathbf{~ m L}^{-\mathbf{1}}\right)\end{array}$ & B. megaterium & P. fluorescens \\
\hline IAA & 0.29 & 10.2 \\
GA3 & 1.81 & 1.95 \\
Cytokinine & 14.92 & 18.39 \\
Amylase & + & - \\
Phosphatase & ++ & - \\
Protease & ++ & - \\
\hline
\end{tabular}

Fresh liquid cultures of Azotobacter chrocococcum, $B$. megaterium and $P$. fluorescence were applied to soil inoculation at the rate of 108 colony forming unit $(\mathrm{cfu} / \mathrm{ml})$. Rhizosphere soil samples were collected after plant harvest. For mycorrhizal inoculation, mycorrhizae spores were isolated from soil pre-inoculated with mycorrhiza (Glomus macrocarpium) by wet-sieving and decantation method as described by Gerdeman and Nicolson (1963). The samples were analyzed for total counts of microorganisms according to Nautiyal (1999). Counting of the growing phosphate dissolving bacteria was carried out by using Pikovskaya's agar medium (PVK) according to Goenadi et al. (2000). Counting and growing Azotobacter was done by modified Ashby's media (Hill, 2000). Pseudomonas, $\mathrm{CO}_{2}$ evolution was determined by Kings media according to Anderson (1982). Plant samples were collected at harvest. Plant height, weight of seeds plant ${ }^{-1}$, weight of straw plant ${ }^{-1}$, yields of seeds straw ha ${ }^{-1}$. Seed oil content was determined using the soxhlet extraction method with hexane as described in AOAC (1990). Stalk defoliated plants were collected for retting process as described by Sanio et al. (1995). The plant samples were first washed by tap water then by distilled water and oven-dried, ground and wet digested by $\mathrm{H}_{2} \mathrm{SO}_{4}$ and $\mathrm{H}_{2} \mathrm{O}_{2}$ as reported by Carter (1993) to determine plant content of $\mathrm{N}, \mathrm{P}$ and $\mathrm{K}$ according to Cottenie et al. (1982). The data were statistically analyzed according to (Snedecor and Cochran 1980) with the aid of CoStat computer program (version 6.4) for statistics.
Differences among treatments were tested with LSD at a $5 \%$ level of significance.

\section{RESULTS AND DISCUSSION}

\section{Safflower yield components:}

Table (5) showed that yield components of safflower plants increased with increasing of farmyard manure, SP (superphosphate), RP (rock phosphate) application rates and with using two types of bio-P fertilizers applications under saline condition of Ras Sudr soil during the studied two growth seasons. $\mathrm{RP}_{2}$ treatments showed higher significant increases of yield parameters than $\mathrm{RP}_{1}$ treatments indicating relative increases of 2.7, 12.4 and 9.9 for stalk ( $\mathrm{kg} / \mathrm{fed})$, seeds $(\mathrm{kg} / \mathrm{fed})$ and oil\%, respectively, while $\mathrm{SP}_{2}$ treatments caused higher increases than $\mathrm{SP}_{1}$ by $1.9,9.1$ and $7.0 \%$.

The SP showed relative increases of yield components as 29.0, 26.8 and $26.6 \%$ for stalk, seeds and oil content, respectively, over the RP. The bio-PS increased these parameters by $11.7,11.2$ and $3.1 \%$ over the bio-VAM. FYM 2 increased yield components over $\mathrm{FYM}_{1}$ by $11.0,15.3$ and $19.7 \%$, respectively. These results agree with those obtained by Rabie et al. (2010), Ghasemi et al. (2012), Ali and Mahmoud (2012) and Amin and Moayedi (2014).

Yield and its components increased with combination of mineral and bio-fertilizers and FYM application (Figs 1 to 3 ). The effect of treatments on yield could be arranged as follows: RP2 + (VAM) + FYM1 $<$ SP2 + (VAM) + FYM1 $<$ SP2 + (PS) + FYM1 $<\mathrm{SP} 2+(\mathrm{VAM}+\mathrm{PS})+\mathrm{FYM} 1<\mathrm{SP} 2+(\mathrm{VAM}+\mathrm{PS})+$ FYM2. The (SP2+VAM+PS+FYM2) treatment produced the highest yield. These results agree with those reported by Neetu et al. (2012), El-Nagdy et al. (2010), Yasin et al. (2012) and Amin and Moayedi (2014).

Nutrients concentrations and uptake of safflower plant:

Data in Tables 6 and 7 showed that the $\mathrm{RP}_{2}$ surpassed $\mathrm{RP}_{1}$ for nutrients contents in stalk and seeds and $\mathrm{SP}_{2}$ surpassed $\mathrm{SP}_{1}$. The $\mathrm{SP}$ recorded higher relative increases of nutrients contents and uptake in 
stalk than RP by $29.9,29.6$ and $28.9 \%$ for N, P and K respectively, and $20.2,32.6$ and $27.8 \%$ respectively in seeds. These results agree with those found by ElNagdy et al. (2010), Yasin et al. (2012) and Amin and Moayedi (2014). The VAM treatment caused lower content of nutrients in stalk than $P$ - bio-fertilizers by relative values of $3.9,9.7$ and $3.8 \%$ for $\mathrm{N}, \mathrm{P}$ and $\mathrm{K}$ respectively and $2.1,7.4$ and $2.6 \%$ respectively in seeds. The FYM treatment increased nutrients contents in stalk by relative increases of 5.7, 12.6 and $5.9 \%$ for $\mathrm{N}, \mathrm{P}$ and $\mathrm{K}$ respectively, and $3.7,10.4$ and $4.4 \%$ in seeds.

Table 5. Effect of fertilizers treatments on the yield and yield component of safflower

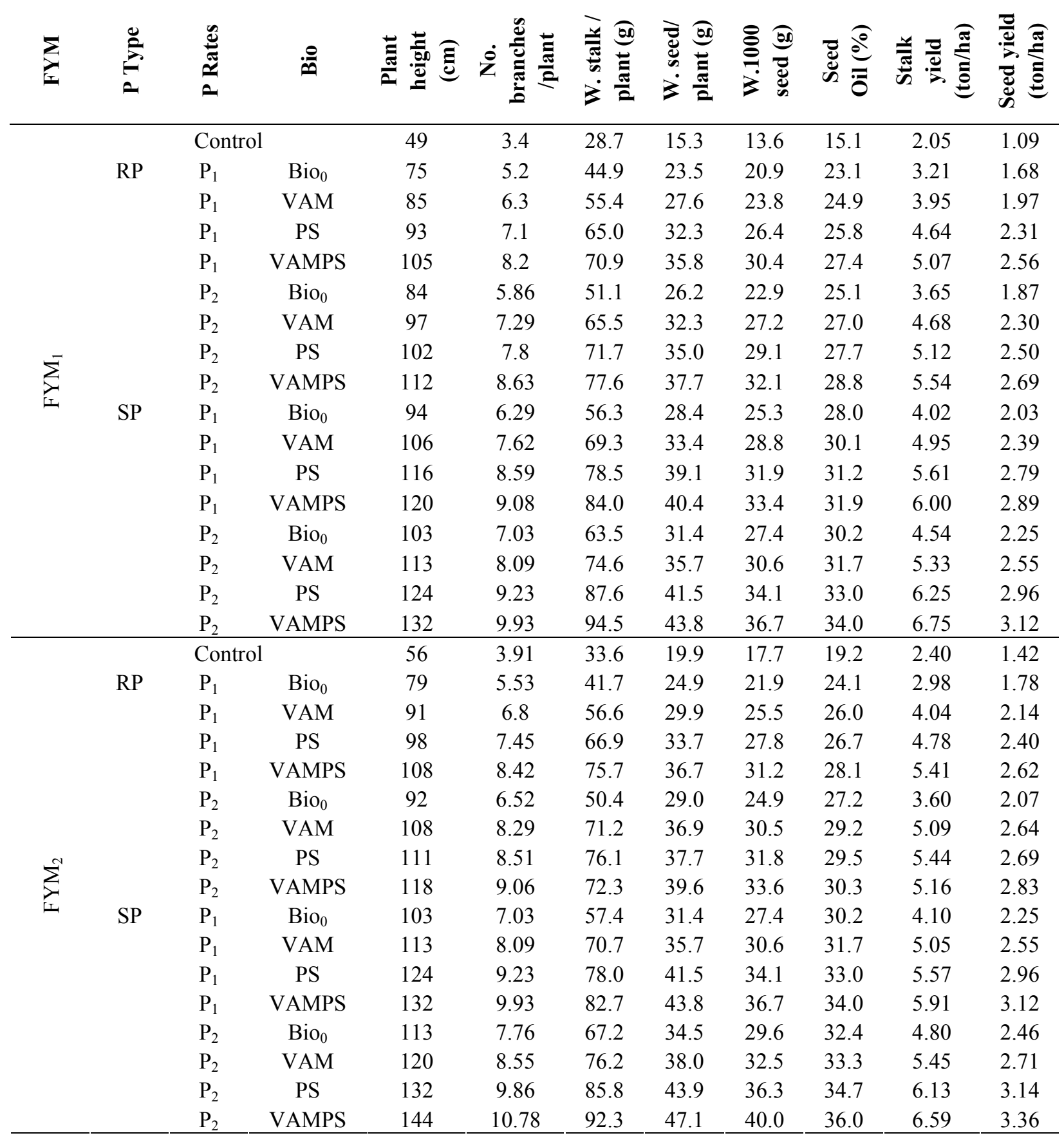


Table 5. Continue (LSD $5 \%$ )

\begin{tabular}{|c|c|c|c|c|c|c|c|c|}
\hline Variables & 氞 & 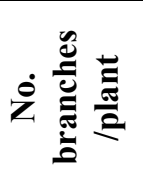 & 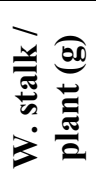 & 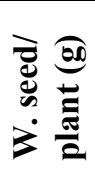 & 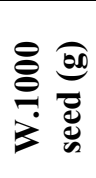 & 峞 & 兰 름 & 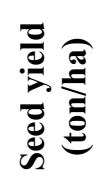 \\
\hline FYM & 0.67 & 0.05 & 0.12 & 0.21 & 0.17 & 0.15 & 0.010 & 0.019 \\
\hline P Types & 1.28 & 0.08 & 0.81 & 0.35 & 0.29 & 0.32 & 0.057 & 0.025 \\
\hline$P$ rates & 0.52 & 0.04 & 0.37 & 0.17 & 0.14 & 0.11 & 0.028 & 0.012 \\
\hline Bio & 1.27 & 0.10 & 0.91 & 0.41 & 0.34 & 0.26 & 0.068 & 0.029 \\
\hline FYM x PT & 0.80 & 0.05 & 0.51 & 0.22 & 0.18 & 0.20 & 0.035 & 0.016 \\
\hline FYM x PR & 0.73 & 0.06 & 0.53 & 0.24 & 0.19 & 0.15 & 0.015 & 0.017 \\
\hline FYM x Bio & 0.44 & 0.10 & 0.91 & 0.41 & 0.34 & 0.09 & 0.068 & 0.029 \\
\hline PT x PR & 0.90 & 0.07 & 0.20 & 0.29 & 0.24 & 0.19 & 0.048 & 0.021 \\
\hline PT x Bio & 1.27 & 0.10 & 0.91 & 0.41 & 0.34 & 0.26 & 0.068 & 0.029 \\
\hline PR $x$ Bio & 1.27 & 0.10 & 0.91 & 0.41 & 0.34 & 0.26 & 0.068 & 0.029 \\
\hline FYM x PT x PR & 1.27 & 0.10 & 0.91 & 0.41 & 0.34 & 0.26 & 0.021 & 0.029 \\
\hline FYM x PT x Bio & 1.27 & 0.10 & 0.91 & 0.41 & 0.34 & 0.13 & 0.068 & 0.029 \\
\hline FYM x PR x Bio & 0.63 & 0.05 & 0.91 & 0.20 & 0.17 & 0.13 & 0.068 & 0.014 \\
\hline PT x PR x Bio & 1.27 & 0.10 & 0.91 & 0.41 & 0.34 & 0.26 & 0.068 & 0.029 \\
\hline FYM x PT x PR x Bio & 0.89 & 0.07 & 0.91 & 0.29 & 0.24 & 0.19 & 0.068 & 0.020 \\
\hline
\end{tabular}

Notes: Treatment designations are as follows: OM1 and OM2 farmyard manure at 24 and $48 \mathrm{~m}^{3} \mathrm{ha}^{-1}$, SP \& RP at rates $31 \& 62$ $\mathrm{kg} \mathrm{P} \mathrm{ha}^{-1}$ respectively ; PS: biofertilization with P-solubilizing bacteria $B$. megaterium \& P. fluorescence Bio $_{0}$ : no biofertilization; VAM : biofertilization using VAM (Vesicular-arbuscular mycorrhiza).

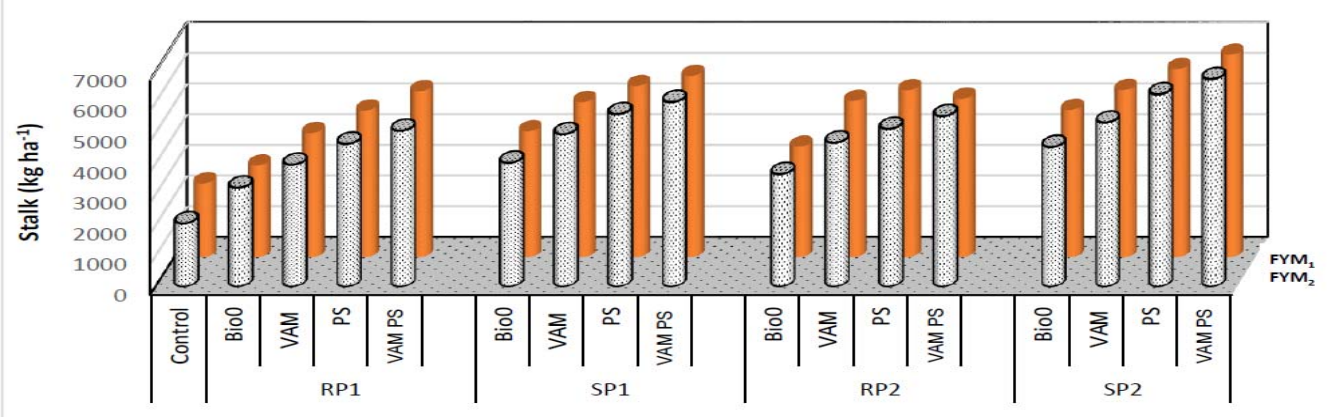

Fig.1. The relation between the studied treatments and the stalk yield of safflower plant

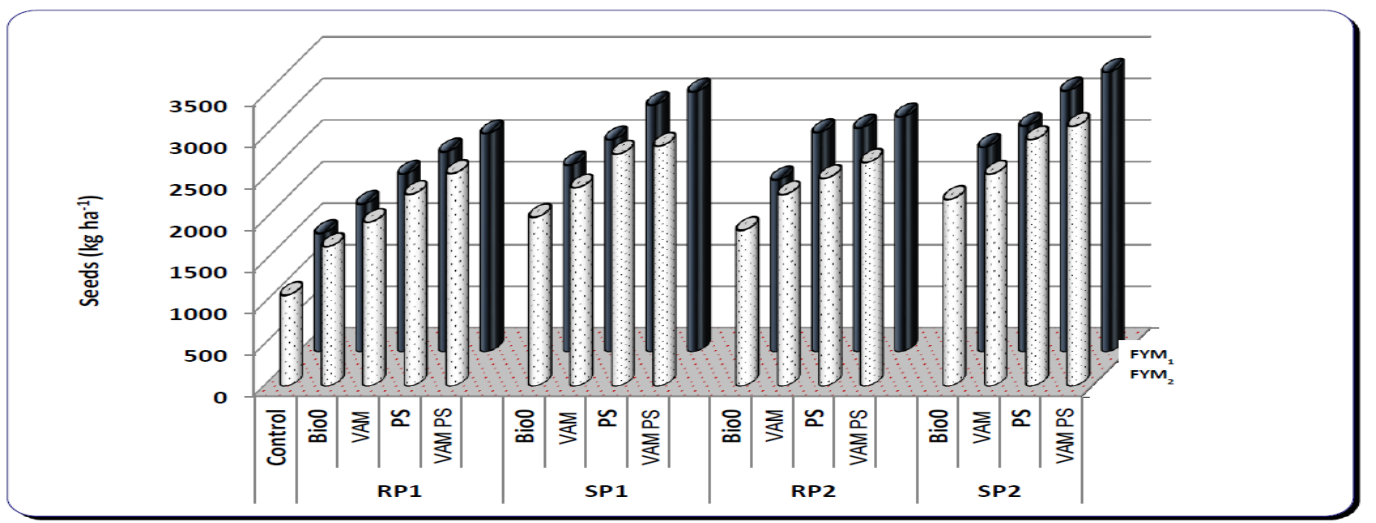

Fig.2. The relation between the studied treatments and the seeds yield of safflower plant 


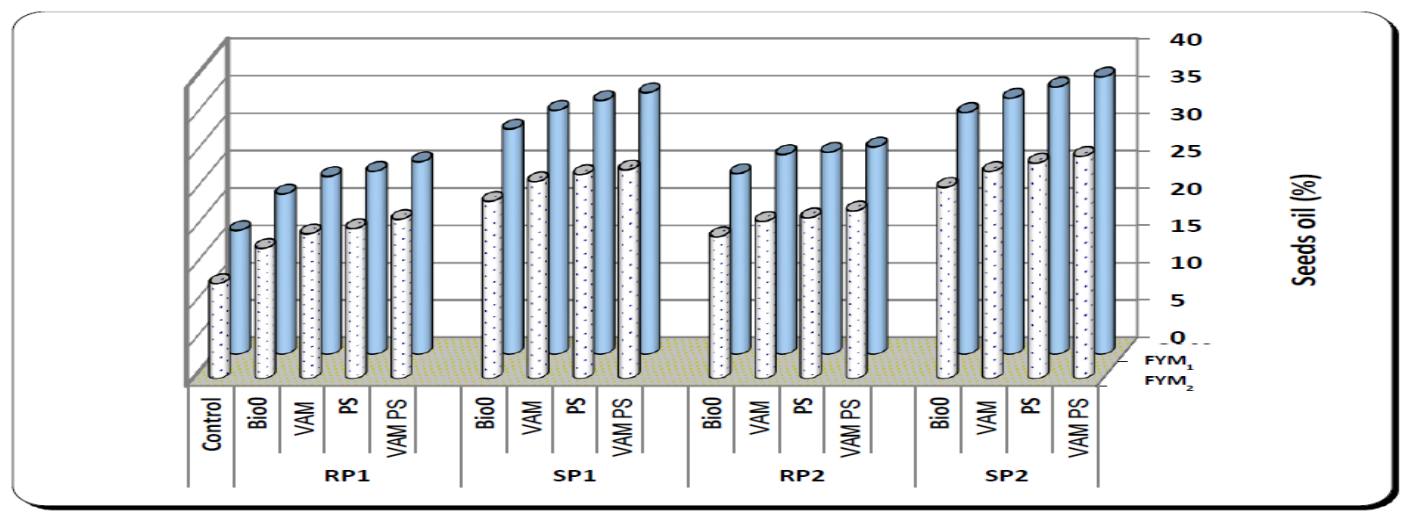

Fig.3. The relation between the studied treatments and oil\% of safflower seeds

Table 6. Effect of fertilizers treatments on nutrients concentrations in stalks and seeds of safflower plants

\begin{tabular}{|c|c|c|c|c|c|c|c|c|c|}
\hline \multirow[b]{2}{*}{ FYM } & \multirow[b]{2}{*}{ P Type } & \multirow[b]{2}{*}{ P Rates } & \multirow[b]{2}{*}{ Bio } & \multicolumn{3}{|c|}{ Stalk nutrients concentration } & \multicolumn{3}{|c|}{ Seeds nutrients concentration } \\
\hline & & & & $\mathbf{N} \%$ & $\mathbf{P \%}$ & $\mathbf{K} \%$ & $\mathbf{N} \%$ & $\mathbf{P \%}$ & $\mathbf{K} \%$ \\
\hline \multirow{17}{*}{ 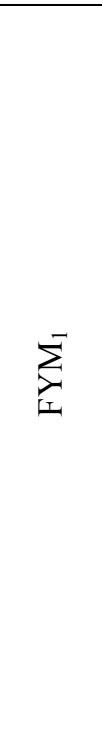 } & & Control & & 0.61 & 0.17 & 0.47 & 1.07 & 0.21 & 0.81 \\
\hline & $\mathrm{RP}$ & $\mathrm{P}_{1}$ & $\mathrm{Bio}_{0}$ & 0.92 & 0.27 & 0.73 & 1.65 & 0.32 & 1.25 \\
\hline & & $\mathrm{P}_{1}$ & VAM & 0.95 & 0.31 & 0.76 & 1.69 & 0.36 & 1.29 \\
\hline & & $\mathrm{P}_{1}$ & PS & 0.98 & 0.34 & 0.81 & 1.73 & 0.39 & 1.33 \\
\hline & & $P_{1}$ & VAMPS & 1.08 & 0.39 & 0.87 & 1.81 & 0.46 & 1.39 \\
\hline & & $\mathrm{P}_{2}$ & $\mathrm{Bio}_{0}$ & 0.98 & 0.32 & 0.81 & 1.74 & 0.39 & 1.33 \\
\hline & & $\mathrm{P}_{2}$ & VAM & 1.03 & 0.35 & 0.83 & 1.78 & 0.43 & 1.37 \\
\hline & & $\mathrm{P}_{2}$ & PS & 1.07 & 0.39 & 0.86 & 1.84 & 0.47 & 1.41 \\
\hline & & $\mathrm{P}_{2}$ & VAMPS & 1.15 & 0.45 & 0.92 & 1.92 & 0.55 & 1.50 \\
\hline & SP & $\mathrm{P}_{1}$ & $\mathrm{Bio}_{0}$ & 1.17 & 0.33 & 0.95 & 1.86 & 0.44 & 1.56 \\
\hline & & $P_{1}$ & VAM & 1.21 & 0.36 & 0.98 & 1.89 & 0.48 & 1.59 \\
\hline & & $\mathrm{P}_{1}$ & PS & 1.25 & 0.41 & 1.02 & 1.93 & 0.51 & 1.63 \\
\hline & & $\mathrm{P}_{1}$ & VAMPS & 1.32 & 0.49 & 1.1 & 1.99 & 0.59 & 1.72 \\
\hline & & $\mathrm{P}_{2}$ & $\mathrm{Bio}_{0}$ & 1.25 & 0.39 & 0.97 & 1.95 & 0.52 & 1.64 \\
\hline & & $\mathrm{P}_{2}$ & VAM & 1.31 & 0.45 & 1.03 & 1.98 & 0.56 & 1.68 \\
\hline & & $\mathrm{P}_{2}$ & PS & 1.37 & 0.51 & 1.05 & 2.02 & 0.59 & 1.73 \\
\hline & & $\mathrm{P}_{2}$ & VAMPS & 1.43 & 0.59 & 1.15 & 2.08 & 0.67 & 1.82 \\
\hline \multirow{17}{*}{ 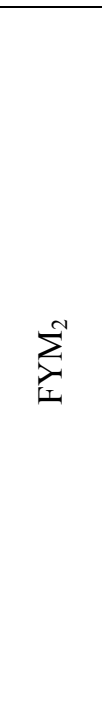 } & & Control & & 0.65 & 0.19 & 0.51 & 1.15 & 0.26 & 0.86 \\
\hline & $\mathrm{RP}$ & $\mathrm{P}_{1}$ & $\mathrm{Bio}_{0}$ & 0.97 & 0.29 & 0.78 & 1.73 & 0.36 & 1.29 \\
\hline & & $P_{1}$ & VAM & 1.01 & 0.35 & 0.81 & 1.76 & 0.39 & 1.33 \\
\hline & & $P_{1}$ & PS & 1.05 & 0.40 & 0.86 & 1.79 & 0.44 & 1.37 \\
\hline & & $\mathrm{P}_{1}$ & VAMPS & 1.12 & 0.43 & 0.91 & 1.89 & 0.51 & 1.46 \\
\hline & & $\mathrm{P}_{2}$ & $\mathrm{Bio}_{0}$ & 1.05 & 0.37 & 0.85 & 1.82 & 0.46 & 1.41 \\
\hline & & $\mathrm{P}_{2}$ & VAM & 1.09 & 0.42 & 0.88 & 1.85 & 0.49 & 1.45 \\
\hline & & $\mathrm{P}_{2}$ & PS & 1.16 & 0.46 & 0.91 & 1.89 & 0.53 & 1.49 \\
\hline & & $\mathrm{P}_{2}$ & VAMPS & 1.22 & 0.52 & 0.99 & 1.97 & 0.61 & 1.57 \\
\hline & SP & $\mathrm{P}_{1}$ & $\mathrm{Bio}_{0}$ & 1.22 & 0.38 & 0.99 & 1.91 & 0.49 & 1.60 \\
\hline & & $P_{1}$ & VAM & 1.26 & 0.43 & 1.02 & 1.95 & 0.53 & 1.64 \\
\hline & & $P_{1}$ & PS & 1.31 & 0.47 & 1.05 & 1.99 & 0.57 & 1.67 \\
\hline & & $P_{1}$ & VAMPS & 1.39 & 0.55 & 1.14 & 2.07 & 0.66 & 1.83 \\
\hline & & $\mathrm{P}_{2}$ & $\mathrm{Bio}_{0}$ & 1.34 & 0.48 & 1.06 & 2.02 & 0.57 & 1.71 \\
\hline & & $\mathrm{P}_{2}$ & VAM & 1.39 & 0.52 & 1.11 & 2.06 & 0.61 & 1.75 \\
\hline & & $\mathrm{P}_{2}$ & PS & 1.43 & 0.55 & 1.15 & 2.09 & 0.65 & 1.79 \\
\hline & & $\mathrm{P}_{2}$ & VAMPS & 1.5 & 0.64 & 1.21 & 2.17 & 0.73 & 1.88 \\
\hline
\end{tabular}


Table 6. continue (LSD 5\%)

\begin{tabular}{lcccccc}
\hline Variables & \multicolumn{3}{c}{ Stalk nutrients concentration } & \multicolumn{3}{c}{ Seeds nutrients concentration } \\
\hline LSD $_{\mathbf{0 . 0 5}}$ & $\mathbf{N} \%$ & $\mathbf{P \%}$ & $\mathbf{K} \%$ & $\mathbf{N \%}$ & $\mathbf{P} \%$ & $\mathbf{K \%}$ \\
\hline FYM & 0.007 & 0.005 & 0.005 & 0.007 & 0.005 & 0.007 \\
P Types & 0.017 & 0.006 & 0.013 & 0.012 & 0.008 & 0.019 \\
P rates & 0.005 & 0.004 & 0.003 & 0.005 & 0.004 & 0.005 \\
Bio & 0.012 & 0.010 & 0.008 & 0.012 & 0.010 & 0.012 \\
FYM x PT & 0.010 & 0.004 & 0.008 & 0.007 & 0.005 & 0.012 \\
FYM x PR & 0.007 & 0.006 & 0.005 & 0.003 & 0.006 & 0.007 \\
FYM x Bio & 0.012 & 0.010 & 0.008 & 0.004 & 0.010 & 0.012 \\
PT x PR & 0.009 & 0.007 & 0.006 & 0.003 & 0.007 & 0.009 \\
PT x Bio & 0.012 & 0.010 & 0.008 & 0.012 & 0.010 & 0.012 \\
PR x Bio & 0.012 & 0.010 & 0.008 & 0.012 & 0.010 & 0.012 \\
FYM x PT x PR & 0.004 & 0.010 & 0.008 & 0.012 & 0.010 & 0.012 \\
FYM x PT x Bio & 0.006 & 0.010 & 0.004 & 0.006 & 0.005 & 0.006 \\
FYM x PR x Bio & 0.006 & 0.010 & 0.004 & 0.006 & 0.005 & 0.012 \\
PT x PR x Bio & 0.006 & 0.010 & 0.008 & 0.006 & 0.005 & 0.006 \\
FYM x PT x PR x Bio & 0.009 & 0.010 & 0.008 & 0.008 & 0.007 & 0.009 \\
\hline
\end{tabular}

See footnotes of Table 5 for treatment designations

Nutrients contents in stalk and seeds of safflower plants increased as a result of combining more than fertilization treatments (Table 6). The bilateral, triple and tetra interaction between studied treatments assured significant effects on the studied parameters. The SP treatments showed significant increases nutrients content than RP treatments. Also, bio-PS fertilizer treatments were superior for nutrients contents as compared with bio-VA treatments (Table 6). The Pbacterial biofertilizers treatments were superior VAM .The $\mathrm{SP}_{2}+\mathrm{VAM}+\mathrm{PS}+\mathrm{FYM}_{2}$ gave the highest nutrients content during the studied two sequence seasons. The results agree with those obtained by Neetu et al. (2012), Yasin et al. (2012) and El Mokadem and Sorour (2014).

The N, P and $\mathrm{K}$ uptake increased with increasing of farmyard manure, RP and SP rates with the biofertilizers. The SP treatments gave higher increases than RP treatments $\mathrm{FYM}_{2}$ caused higher increases of nutrients uptake (Table 7) than $\mathrm{FYM}_{1}$. Nutrient uptake by plants increased with combination of mineral and bio P fertilizers with FYM application. The bilateral, triple and tetra interaction between studied treatments assure that SP treatments showed higher significant increases for nutrients uptake by safflower plant than RP treatments. On the other side, bio-PS fertilizer treatments were superior for nutrients uptake when compared with bio-VAM treatments. The combination of farmyard manure, mineral P-fertilizers and biofertilizers applications produced the most effective treatment $\left(\mathrm{SP}_{2}+\mathrm{VAM}+\mathrm{PS}+\mathrm{FYM}_{2}\right)$ which achieved the highest nutrients uptake by stalk and seeds of safflower plant when compared with the other studied treatments. The current results agreed with those obtained by Rabie et al. (2010), Ali and Mahmoud (2012), Weisany et al. (2013) and Raju et al. (2013).

\section{Microbial activities in rhizosphere:}

Initial total microbial counts in Ras Sudr soil of Sinai were $30 \times 10^{5} \mathrm{cfu} / \mathrm{g}$ dry soil. Data in Table (8) showed that total microbial counts in the rhizosphere tended to increase by treatments receiving fertilizers. The highest counts were obtained with $\mathrm{FYM}_{2}, \mathrm{RP}$ and SP applications. Microbial respiration $\left(\mathrm{CO}_{2}\right.$ evolution) increased after long term from $\mathrm{P}$ addition; Microbial activity increase in the presence of $\mathrm{P}$ and allowed rapid transformation of soil organic matter. The carbon dioxide $\left(\mathrm{CO}_{2}\right)$ is an indication of the biological activity in the rhizosphere. The treatment combining farmyard manure, mineral and bio-fertilizer gave the highest $\mathrm{CO}_{2}$ evolution. Data of $\mathrm{CO}_{2}$ evolution were in harmony with those of total microbial counts. These results agree with those found by Visser and Dennis (1992), Gilliam et al. (2011) and Liu et al. (2012). The control treatment or the non-treated treatment showed the lowest value, the bio-fertilizers and mineral fertilizers treatments showed the highest positive counts with additions of FYM2, RP and SP at the high rates. These results agree with those obtained by Yasin et al. (2012), Neetu et al. (2012) and El Mokadem and Sorour (2014). The results obtained showed that combining bio-fertilizers with mineral fertilizers could be useful to obtain safflower yield increases. It is also clear that application of VAM and $B$. megatherium increased both the amounts of the available nutrients in soil, plant growth, soil fertility and counts of microbial communities. These results agree with those obtained by Yadav et al. (2007) and Daneshmandi et al. (2012). 
Table 7. Effect of fertilizers treatments on the nutrients uptake by safflower plants

\begin{tabular}{|c|c|c|c|c|c|c|c|c|c|}
\hline \multirow[b]{2}{*}{ FYM } & \multirow[b]{2}{*}{ P type } & \multirow[b]{2}{*}{ P Rates } & \multirow[b]{2}{*}{ Bio } & \multicolumn{3}{|c|}{ stalk nutrients uptake $\left(\mathrm{kg} \mathrm{ha}^{-1}\right)$} & \multicolumn{3}{|c|}{ Seeds nutrients uptake $\left(\mathrm{kg} \mathrm{ha}^{-1}\right)$} \\
\hline & & & & $\mathbf{N}$ & $\mathbf{P}$ & $\mathbf{K}$ & $\mathbf{N}$ & $\mathbf{P}$ & $\mathbf{K}$ \\
\hline \multirow{17}{*}{$\sum_{i}^{\bar{\lambda}}$} & \multirow{17}{*}{ SP } & Control & & 12.5 & 3.5 & 9.6 & 11.7 & 2.3 & 8.8 \\
\hline & & $\mathrm{P}_{1}$ & $\mathrm{BiO}_{0}$ & 29.5 & 8.7 & 23.4 & 27.7 & 5.4 & 21.0 \\
\hline & & $\mathrm{P}_{1}$ & VAM & 37.5 & 12.2 & 30.0 & 33.3 & 7.1 & 25.4 \\
\hline & & $\mathrm{P}_{1}$ & PS & 45.5 & 15.8 & 37.6 & 40.0 & 9.0 & 30.7 \\
\hline & & $\mathrm{P}_{1}$ & VAMPS & 54.8 & 19.8 & 44.1 & 46.3 & 11.8 & 35.6 \\
\hline & & $\mathrm{P}_{2}$ & $\mathrm{BiO}_{0}$ & 35.8 & 11.7 & 29.6 & 32.5 & 7.3 & 24.9 \\
\hline & & $\mathrm{P}_{2}$ & VAM & 48.2 & 16.4 & 38.8 & 40.9 & 9.9 & 31.5 \\
\hline & & $\mathrm{P}_{2}$ & PS & 54.8 & 20.0 & 44.0 & 46.0 & 11.8 & 35.3 \\
\hline & & $\mathrm{P}_{2}$ & VAMPS & 63.7 & 24.9 & 51.0 & 51.6 & 14.8 & 40.4 \\
\hline & & $\mathrm{P}_{1}$ & $\mathrm{Bio}_{0}$ & 47.0 & 13.3 & 38.2 & 37.8 & 8.9 & 31.7 \\
\hline & & $\mathrm{P}_{1}$ & VAM & 59.9 & 17.8 & 48.5 & 45.2 & 11.5 & 38.0 \\
\hline & & $\mathrm{P}_{1}$ & PS & 70.1 & 23.0 & 57.2 & 53.8 & 14.2 & 45.5 \\
\hline & & $\mathrm{P}_{1}$ & VAMPS & 79.2 & 29.4 & 66.0 & 57.5 & 17.1 & 49.7 \\
\hline & & $\mathrm{P}_{2}$ & $\mathrm{BiO}_{0}$ & 56.8 & 17.7 & 44.0 & 43.9 & 11.7 & 36.9 \\
\hline & & $\mathrm{P}_{2}$ & VAM & 69.8 & 24.0 & 54.9 & 50.5 & 14.3 & 42.8 \\
\hline & & $\mathrm{P}_{2}$ & PS & 85.6 & 31.9 & 65.6 & 59.8 & 17.5 & 51.2 \\
\hline & & $\mathrm{P}_{2}$ & VAMPS & 96.5 & 39.8 & 77.6 & 64.9 & 20.9 & 56.8 \\
\hline \multirow{17}{*}{$\sum_{i}^{N}$} & \multirow{17}{*}{ SP } & Control & & 15.6 & 4.6 & 12.2 & 16.3 & 3.7 & 12.2 \\
\hline & & $P_{1}$ & $\mathrm{BiO}_{0}$ & 28.9 & 8.6 & 23.2 & 30.8 & 6.4 & 23.0 \\
\hline & & $\mathrm{P}_{1}$ & VAM & 40.8 & 14.1 & 32.7 & 37.7 & 8.3 & 28.5 \\
\hline & & $\mathrm{P}_{1}$ & PS & 50.2 & 19.1 & 41.1 & 43.0 & 10.6 & 32.9 \\
\hline & & $\mathrm{P}_{1}$ & VAMPS & 60.6 & 23.3 & 49.2 & 49.5 & 13.4 & 38.3 \\
\hline & & $\mathrm{P}_{2}$ & $\mathrm{Bio}_{0}$ & 37.8 & 13.3 & 30.6 & 37.7 & 9.5 & 29.2 \\
\hline & & $\mathrm{P}_{2}$ & VAM & 55.5 & 21.4 & 44.8 & 48.8 & 12.9 & 38.3 \\
\hline & & $\mathrm{P}_{2}$ & PS & 63.1 & 25.0 & 49.5 & 50.8 & 14.3 & 40.1 \\
\hline & & $\mathrm{P}_{2}$ & VAMPS & 63.0 & 26.8 & 51.1 & 55.8 & 17.3 & 44.4 \\
\hline & & $\mathrm{P}_{1}$ & $\mathrm{Bio}_{0}$ & 50.0 & 15.6 & 40.6 & 43.0 & 11.0 & 36.0 \\
\hline & & $\mathrm{P}_{1}$ & VAM & 63.6 & 21.7 & 51.5 & 49.7 & 13.5 & 41.8 \\
\hline & & $\mathrm{P}_{1}$ & PS & 73.0 & 26.2 & 58.5 & 58.9 & 16.9 & 49.4 \\
\hline & & $P_{1}$ & VAMPS & 82.1 & 32.5 & 67.4 & 64.6 & 20.6 & 57.1 \\
\hline & & $\mathrm{P}_{2}$ & $\mathrm{Bio}_{0}$ & 64.3 & 23.0 & 50.9 & 49.7 & 14.0 & 42.1 \\
\hline & & $\mathrm{P}_{2}$ & VAM & 75.8 & 28.3 & 60.5 & 55.8 & 16.5 & 47.4 \\
\hline & & $\mathrm{P}_{2}$ & PS & 87.7 & 33.7 & 70.5 & 65.6 & 20.4 & 56.2 \\
\hline & & $\mathrm{P}_{2}$ & VAMPS & 98.9 & 42.2 & 79.7 & 72.9 & 24.5 & 63.2 \\
\hline
\end{tabular}

Table 7. continue (LSD 5\%)

\begin{tabular}{lcccccc}
\hline Variables & \multicolumn{3}{c}{ stalk nutrients uptake $\left(\mathbf{k g ~ h a}^{-\mathbf{1}}\right)$} & \multicolumn{3}{c}{ Seeds nutrients uptake (kg ha-1) } \\
\hline LSD $_{\mathbf{0 . 0 5}}$ & $\mathbf{N}$ & $\mathbf{P}$ & $\mathbf{K}$ & $\mathbf{N}$ & $\mathbf{P}$ & $\mathbf{K}$ \\
\hline FYM & 0.30 & 0.23 & 0.26 & 0.45 & 0.19 & 0.37 \\
P Types & 1.52 & 0.54 & 1.21 & 0.78 & 0.32 & 0.87 \\
P rates & 0.57 & 0.32 & 0.42 & 0.34 & 0.16 & 0.31 \\
Bio & 1.41 & 0.77 & 1.02 & 0.84 & 0.40 & 0.75 \\
FYM x PT & 0.95 & 0.34 & 0.76 & 0.49 & 0.46 & 0.55 \\
FYM x PR & 0.81 & 0.45 & 0.59 & 0.49 & 0.23 & 0.43 \\
FYM x Bio & 1.41 & 0.77 & 1.02 & 0.29 & 0.40 & 0.75 \\
PT x PR & 1.00 & 0.55 & 0.72 & 0.60 & 0.09 & 0.17 \\
PT x Bio & 1.41 & 0.77 & 1.02 & 0.84 & 0.40 & 0.75 \\
PR x Bio & 1.41 & 0.77 & 1.02 & 0.84 & 0.40 & 0.75 \\
FYM x PT x PR & 1.41 & 0.24 & 1.02 & 0.84 & 0.40 & 0.75 \\
FYM x PT x Bio & 1.41 & 0.77 & 1.02 & 0.84 & 0.40 & 0.75 \\
FYM x PR x Bio & 1.41 & 0.77 & 1.02 & 0.42 & 0.20 & 0.37 \\
PT x PR x Bio & 1.41 & 0.77 & 1.02 & 0.84 & 0.40 & 0.75 \\
FYM x PT x PR x Bio & 0.99 & 0.77 & 1.02 & 0.59 & 0.28 & 0.52 \\
\hline
\end{tabular}

See footnotes of Table 5 for treatment designations 
Table 8. Effect of the studied treatments on microbial activities in rhizosphere soil of safflower plants

\begin{tabular}{|c|c|c|c|c|c|c|c|c|}
\hline FYM & $\begin{array}{c}\text { P } \\
\text { Type }\end{array}$ & $\begin{array}{c}\mathbf{P} \\
\text { Rates }\end{array}$ & Bio & $\begin{array}{c}\text { Total microbial } \\
\text { Counts } \\
\left(\times 10^{2} \mathrm{cfu} / \mathrm{g} \text { D.S }\right)\end{array}$ & $\begin{array}{c}\text { PDB counts } \\
\left(\times 10^{2} \mathrm{cfu} / \mathrm{g} D . S\right)\end{array}$ & $\begin{array}{c}\text { Azotobacter } \\
\text { densities } \\
\left(\times 10^{3} \text { cells } / \mathbf{g} \text { D.S }\right)\end{array}$ & $\begin{array}{c}\text { Ps counts } \\
\left(\times 10^{2} \mathrm{cfu} / \mathrm{g} D . S\right)\end{array}$ & \multirow{2}{*}{$\begin{array}{r}\mathrm{CO}_{2} \\
\mathrm{mg} / \mathbf{1 0 0 g} \\
\text { D.S /24hr } \\
4.80\end{array}$} \\
\hline \multirow{17}{*}{ 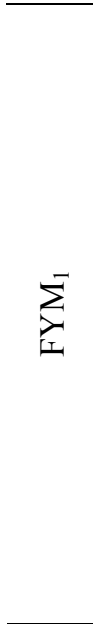 } & \multirow{3}{*}{$\mathrm{RP}$} & Control & & \multirow{2}{*}{$\begin{array}{l}24 \\
30\end{array}$} & 3.20 & 5.90 & 1.20 & \\
\hline & & $P_{1}$ & $\mathrm{Bio}_{0}$ & & 4.30 & 6.40 & 2.10 & 6.10 \\
\hline & & $P_{1}$ & VAM & 70 & 6.90 & 8.50 & 3.70 & 7.00 \\
\hline & & $\mathrm{P}_{1}$ & PS & 89 & 7.00 & 8.60 & 2.90 & 7.10 \\
\hline & & $\mathrm{P}_{1}$ & VAMPS & 108 & 7.50 & 8.90 & 4.10 & 7.40 \\
\hline & & $\mathrm{P}_{2}$ & $\mathrm{Bio}_{0}$ & 31 & 4.60 & 6.30 & 2.20 & 6.15 \\
\hline & & $\mathrm{P}_{2}$ & VAM & 87 & 7.55 & 8.20 & 3.85 & 7.15 \\
\hline & & $\mathrm{P}_{2}$ & PS & 101 & 7.95 & 8.30 & 3.00 & 7.55 \\
\hline & & $\mathrm{P}_{2}$ & VAPS & 127 & 8.20 & 8.50 & 4.35 & 7.80 \\
\hline & SP & $\mathrm{P}_{1}$ & $\mathrm{BiO}_{0}$ & 32 & 4.40 & 6.60 & 2.40 & 6.40 \\
\hline & & $P_{1}$ & VAM & 85 & 7.20 & 8.90 & 4.00 & 7.50 \\
\hline & & $P_{1}$ & PS & 97 & 7.90 & 9.10 & 2.90 & 7.80 \\
\hline & & $P_{1}$ & VAMPS & 128 & 8.20 & 9.70 & 4.20 & 7.90 \\
\hline & & $\mathrm{P}_{2}$ & $\mathrm{BiO}_{0}$ & 35 & 4.80 & 6.55 & 2.35 & 6.60 \\
\hline & & $\mathrm{P}_{2}$ & VAM & 102 & 7.60 & 8.65 & 4.25 & 7.65 \\
\hline & & $\mathrm{P}_{2}$ & PS & 116 & 8.40 & 8.75 & 3.10 & 7.90 \\
\hline & & $\mathrm{P}_{2}$ & VAMPS & 147 & 8.75 & 9.30 & 4.50 & 8.10 \\
\hline & & Contro & & 28 & 3.70 & 6.20 & 1.60 & 5.30 \\
\hline & RP & $\mathrm{P}_{1}$ & $\mathrm{Bio}_{0}$ & 31 & 4.75 & 6.25 & 2.25 & 6.18 \\
\hline & & $\mathrm{P}_{1}$ & VAM & 95 & 7.88 & 8.05 & 3.93 & 7.23 \\
\hline & & $P_{1}$ & PS & 106 & 8.43 & 8.15 & 3.05 & 7.78 \\
\hline & & $P_{1}$ & VAMPS & 136 & 8.55 & 8.30 & 4.48 & 8.00 \\
\hline & & $\mathrm{P}_{2}$ & $\mathrm{BiO}_{0}$ & 31 & 4.90 & 6.20 & 2.30 & 6.20 \\
\hline & & $\mathrm{P}_{2}$ & VAM & 103 & 8.20 & 7.90 & 4.00 & 7.30 \\
\hline 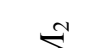 & & $\mathrm{P}_{2}$ & PS & 112 & 8.90 & 8.00 & 3.10 & 8.00 \\
\hline$\sum$ & & $\mathrm{P}_{2}$ & VAMPS & 145 & 8.90 & 8.10 & 4.60 & 8.20 \\
\hline 胥 & SP & $\mathrm{P}_{1}$ & $\mathrm{BiO}_{0}$ & 37 & 5.00 & 6.53 & 2.33 & 6.70 \\
\hline & & $P_{1}$ & VAM & 110 & 7.80 & 8.53 & 4.38 & 7.73 \\
\hline & & $\mathrm{P}_{1}$ & PS & 125 & 8.65 & 8.58 & 3.20 & 7.95 \\
\hline & & $P_{1}$ & VAMPS & 156 & 9.03 & 9.10 & 4.65 & 8.20 \\
\hline & & $\mathrm{P}_{2}$ & $\mathrm{BiO}_{0}$ & 38 & 5.20 & 6.50 & 2.30 & 6.80 \\
\hline & & $\mathrm{P}_{2}$ & VAM & 118 & 8.00 & 8.40 & 4.50 & 7.80 \\
\hline & & $\mathrm{P}_{2}$ & PS & 134 & 8.90 & 8.40 & 3.30 & 8.00 \\
\hline & & $\mathrm{P}_{2}$ & VAMPS & 165 & 9.30 & 8.90 & 4.80 & 8.30 \\
\hline h & c & inue & SD 5\% & & & & & \\
\hline & Vari & ibles & Tota & I microbial & counts & zotobacter & Ps counts & $\mathrm{CO}_{2}$ \\
\hline & LSI & 0.05 & $\left(\times 10^{2}\right.$ & $\begin{array}{l}\text { Counts } \\
\left.{ }^{2} \mathrm{cfu} / \mathrm{g} \text { D.S }\right)\end{array}$ & fu/g D.S) & $\begin{array}{l}\text { densities } \\
0^{3} \text { cells/g D.S ) }\end{array}$ & $\left(\times 10^{2} \mathrm{cfu} / \mathrm{g}\right.$ D.S $)$ & $\begin{array}{c}\mathrm{mg} / 100 \mathrm{~g} \text { D.S } \\
/ 24 \mathrm{hr}\end{array}$ \\
\hline FYN & & & & 1.22 & 0.058 & 0.019 & 0.022 & 0.028 \\
\hline P Ty & & & & 0.86 & 0.019 & 0.030 & 0.013 & 0.024 \\
\hline$P$ rat & & & & 0.52 & 0.022 & 0.011 & 0.006 & 0.009 \\
\hline Bio & & & & 1.27 & 0.055 & 0.026 & 0.016 & 0.021 \\
\hline FYN & $\mathrm{x}$ PT & & & 1.22 & 0.027 & 0.019 & 0.018 & 0.034 \\
\hline FYN & x PR & & & 0.73 & 0.032 & 0.015 & 0.009 & 0.012 \\
\hline FYN & $\mathrm{x}$ Bio & & & 1.27 & 0.055 & 0.026 & 0.016 & 0.021 \\
\hline PT $x$ & & & & 0.89 & 0.039 & 0.006 & 0.011 & 0.015 \\
\hline PT $x$ & Bio & & & 1.27 & 0.055 & 0.026 & 0.016 & 0.021 \\
\hline PR $x$ & Bio & & & 1.27 & 0.055 & 0.026 & 0.016 & 0.021 \\
\hline FYN & x PT x & PR & & 1.27 & 0.055 & 0.008 & 0.005 & 0.021 \\
\hline FYN & x PT x & Bio & & 1.27 & 0.055 & 0.013 & 0.016 & 0.021 \\
\hline FYN & $x$ PR x & Bio & & 1.27 & 0.027 & 0.013 & 0.008 & 0.011 \\
\hline PT $x$ & $P R \times B$ & & & 0.63 & 0.027 & 0.013 & 0.008 & 0.021 \\
\hline FYN & $x$ PT $x$ & PR $\times$ Bio & & 0.89 & 0.038 & 0.018 & 0.011 & 0.015 \\
\hline
\end{tabular}

See footnotes of Table 5 for treatment designations 


\section{CONCLUSION}

Safflower responded positively to application of FYM, superphosphate, rock phosphate and bio fertilizer. Application of VAM fungi and $B$. megatherium increased yield and $\mathrm{N}, \mathrm{P}$ and $\mathrm{K}$ uptake, oil content in seeds and yield. The most effective combination treatment on yield parameters, nutrient content and uptake were $\mathrm{RP}_{2}+(\mathrm{VAM})+\mathrm{FYM}_{1}<\mathrm{SP}_{2}+$ $(\mathrm{VAM})+\mathrm{FYM}_{1}<\mathrm{SP}_{2}+(\mathrm{PS})+\mathrm{FYM} 1<\mathrm{SP}_{2}+$ $(\mathrm{VAM}+\mathrm{PS})+\mathrm{FYM}_{1}<\mathrm{SP}_{2}+(\mathrm{VAM}+\mathrm{PS})+\mathrm{FYM}_{2}$. The combination of mineral fertilizers $\mathrm{P}$ and bio-fertilizers with farmyard manure gave $6647 \mathrm{~kg}$ stalk ha ${ }^{-1}$, and $3390 \mathrm{~kg}$ seeds ha ${ }^{-1}$ and oil content of $360 \mathrm{~g}^{-1} \mathrm{~kg}^{-1}$ seeds. The bilateral, triple and tetra interaction between the studied treatments assured that SP treatment significant increase yield components, nutrients concentrations and uptake of stalk and seeds of safflower plants grown in loamy sand soil in Ras Sudr.

\section{REFERENCES}

Ali, E.A. and A.M. Mahmoud. 2012. Effect of Combination between Organic and Mineral Fertilization on Productivity of Some Safflower Genotypes. World J. Agric. Sci. 8 (2): 134-140.

Amin, F. and M. Moayedi. 2014. Effect of Phosphate and Nitrogene Bio-fertilizers on yield, yield components, oil and protein in sunflower (Helianthus annus L.) Bull. Env. Pharmacol. Life Sci., Vol 3 [Special Issue V]: 110-117.

Anderson, J.P.E. 1982. Soil Respiration. In Methods of soil analysis, part $2,2^{\text {nd }}$ ed., ed. A. L. Page, R. H. Miller, and D. R. Keeney, 837-871. Madison, Wisc.:ASA and SSSA.

AOAC, 1990. Official Methods of Analysis. $14^{\text {th }}$ Ed., Association of Official Analytical Chemist, Arlington, VA., pp: 503-515.

Bergey's Manual of Determinative Bacteriology. 1994. John G Hol, Noel R. Kriey, Peter H.A. Sneath, James T. Staley T.Williams (Ed.) (9 $9^{\text {th }}$ ed.) Williams and Wilkins, Baltimore, London.

Carter, M.R. (Ed.). 1993. Soil Sampling and Methods of Analysis. Canadian Society of Soil Science. Lewis Publishers, London, Tokyo.

Ceulemans,T., R. Merckx, M. Hens and O. Honnay. 2011. A trait-based analysis of the role of phosphorus vs. nitrogen enrichment in plant species loss across North-west European grasslands. J. Appl. Ecology,48(5):1155-1163.

CoStat version 6.400. Copyright $\subset$ 1 1998-2008 CoHort Software. 798 Lighthouse Ave. PMB 320, Monterey, CA, 93940, USA

Cottenie, A., M. Verlso, L. Kilkens, G. Velghe and R. Camerlynck. 1982. Chemical Analysis of Plants and Soils. Lab. Agroch. State Univ. Gent, Belgium.
Daneshmandi, N.G., B. Abdolmahdi and R.R. Mohammad. 2012. International J. Agric. Res. Review. 2 (6): 699-704.

El-Mokadem, E.H. and M. Sorour. 2014. Effect of bio and chemical fertilizers on growth and flowering of Petunia hybrid plants. Am. J. Plant Physiol. 9(2): 68-77.

El-Nagdy, G.A., D.M.A. Nassar, E.A. El-Kady and G.S.A ElYamanee. 2010. Response of flax plant (Linum usitatissimum L.) to treatments with mineral and biofertilizers from nitrogen and phosphorus. J. Am. Sci., 6(10):207-217.

El-Saidy, Aml E.A. and K.M. Abd El-Hai. 2011. Alleviation of peanut seed deterioration during storage using biotic and abiotic agents. Res. J. Seed Sci. ISSN 1819-3552/Doi: 10.3923/rjss, p: 1-13.

Farouk, S. 2011. Ascorbic Acid and $\alpha$-Tocopherol Minimize Salt-Induced Wheat Leaf Senescence. J. Stress Physiol. Biochem. Vol. 7 No. 3.

Gerdeman J.W. and T.H. Nicolson. 1963. Spores of mycorrhizal Endogone species extracted from soil by wet sieving and decanting. Trans. Br. Mycol. Soc. 46, 235244.

Ghasemi, M., M.S. Moghaddasi and A.H. Omidi. 2012. The effects of biological and chemical nitrogen fertilizers on agronomical traits of winter safflower cultivars in saveh region of Iran. Annals Biolog. Res. 3 (11): 5141-5144.

Gilliam, F.S., R.L. McCulley and J.A. Nelson. 2011. Spatial Variability in Soil Microbial Communities in a NitrogenSaturated Hardwood Forest Watershed. Soil Sci.Soc. Am. J., 75: 280-286.

Goenadi, D.H., Siswanto and Y. Sugiarto. 2000. Bioactivation of poorly soluble phosphate rocks with a phosphorussolubilizing fungus. Soil Sci. Soc. Am. J. 64: 927- 932.

Gomez, K.A. and A.A. Gomez. 1984. Statistical Procedures for Agricultural Research. 2nd ed., Wiley sons, New York, USA.

Hamza, M. 2015. Influence of different plant densities on crop yield of six safflower genotypes under Egyptian newly reclaimed soils conditions. Intl J Agri Crop Sci. Vol., 8 (2), 168-173.

Hergert, G.W. and D. Knudsen. 2004. Irrigation Water Quality Criteria. Nebraska, Institute of Agriculture and Natural Resources.

Hill, G.S. 2000. Azotobacter. In Encyclopedia of microbiology $3^{\text {rd }}$ Ed., Academic Press, New York, 2000, pp.359-371.

Kizil, S., Ö. Çakmak, S. Kirici and M. İnan. 2008. A comprehensive study on safflower (Carthamus Tinctorius L.) in semi-arid conditions. Biotechnol. \& Biotechnol. Eq. 947-953.

Klute, A.A. 1986. Methods of Soil Analysis. Part $12^{\text {nd }}$ Ed. Am. Soc. Agron. .Inc. Publishes, Madison, Wisconsin, USA. 
Lambers, H., P.E. Hayes, E. Laliberte, R.S. Oliveira and G. Zemunik. 2014. The role of phosphorus in explaining plant biodiversity patterns and processes in a global biodiversity hotspot. In: Mucina, L., J.N. Price and J.M. Kalwij (Eds.), Biodiversity and vegetation: patterns, processes, conservation, pp. 41-42. Kwongan Foundation, Perth, AU.

Liu, L., P. Gundersen, T. Zhang and J. Mo. 2012. Effects of phosphorus addition on soil microbial biomass and community composition in three forest types in tropical China. Soil Biol. Biochem. 44: 31-38.

Nautiyal, C.S. 1999. An efficient microbiological growth medium for screening phosphate solubilizing microorganisms. FEMS Microbiology Letters, 170: 265270.

Neetu, N., A. Aggarwal, A. Tanwar and A. Alpa. 2012. Influence of arbuscular mycorrhizal fungi and Pseudomonas fluorescens at different superphosphate levels on linseed (Linum usitatissimum L.) growth response. Chilean J. Agric. Res. 72(2): APRIL-JUNE, 237-243.

Oelke, E.A, E.S. Oplinger, T.M. Teynor, D.H. Putnam, J.D. Doll, K.A. Kelling, B.R. Durgan and D.M. Noetzel. 1992. Saflower. Alternative Field Crops Manual, Cooperative Extension, University of Wisconsin, USA.

Olsen, C.R., N.H. Culshall and I.L. Larsen. 1982. Pollutantparticle association and dynamics in coastal marine environments: a review. Marine Chem. 11: 501-533.

Page, A.L., R.H. Miller and D.R. Keeney. 1984. Methods of soil analysis. Part 2: Chemical and Microbiological Properties. Second edition. Agronomy J. 9: 2, Am. Soc. Agron. Inc., Soil Sci. Soc. Am. Inc. Pub. Madison, Wisconsin, USA.
Rabie, K.A.E., H.H. Manaf, H.A.H. Gouda and I.M. Shahat. 2010. Influence of Compost and Rock Amendments on Growth and Active Ingredients of Safflower (Carthamus tinctorius L.). Australian J. Basic Applied Sci. 4(7): 16261631.

Raju, B., P.C. Rao, A.P.K. Reddy and K. Rajesh. 2013. Effect of INM practices on nutrient uptake and seed yield in safflower. Annals Biolog. Res. 4(7): 222-226.

Rizzolo, A.C., J. Baldo and A. Polesello. 1993. Application of high performance liquid chromatography to the analysis of niacin and biotin in Italian almond cultivars, J. Chromatoghraphy, 553:1-2.

Sanio, S.H., C.H. Pape, U. Schunke and C. Matz. 1995. Reduction of time required for dew retting of flax: Influence of agricultural, mechanical and microbiological techniques on fiber processing. Melliand 76: E101-E104.

Snedecor G.W., W.G. Cochran. 1980. Statistical Methods, $18^{\text {th }}$ ed. The Iowa State College Press. Ames, Iowa, USA.

Visser, S. and P. Dennis. 1992. Soil biological criteria as indications of soil quantity: Soil microorganisms. Am. J. Alternative Agric. 7: 33-37.

Weisany, W., Y. Raei and K.H. Allahverdipoor. 2013. Role of Some of Mineral Nutrients in Biological Nitrogen Fixation. Bull. Env. Pharmacol. Life Sci., 2 (4):77-84.

Yadav, E., D.V. Pathak, S.K. Sharma, M. Kumar and P.K. Sharma. 2007. Isolation and characterization of mutants of Pseudomonas maltophila PM-4 altered in chitinolytic activity and antagonistic activity against root rot pathogens of clusterbean (Cyamopsis tetragonoloba L.). Indian J. Microbiol. 47: 64-71.

Yasin, M., W. Mussarat, K. Ahmad, A. Ali, S. Waseem and H. Shah. 2012. Role of biofertilizers in flax for ecofriendly agriculture. Sci. Int. (Lahore), 24(1):95-99. 


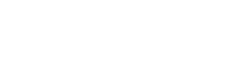 \\ الفلفة اللماد الهضوى ومنيبل الفوفور الحيوبة مع الصخر الفوفلت في الأرالف الجيربة الزبالة

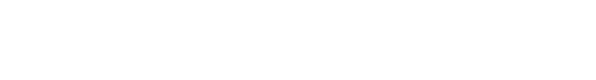 \\ محرم فؤاد علية، عسن عبد العلطى فاوى، رحلب حلم حجلب، نهو موسى محمد}

المذيب ــة لفوس ففور Vascular Arbiscular Mychorrhiza و خلال موس م. B. megatherium (PSB)

(VAM)

الدرلسة. وقد زادت القيلست المحصولية وتركيز المغنيت والممتص مع التكلمل بين المعلملات تحت الدرلسة. وتؤكد

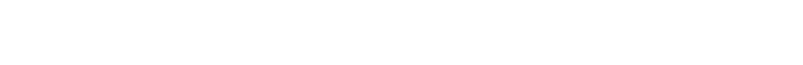

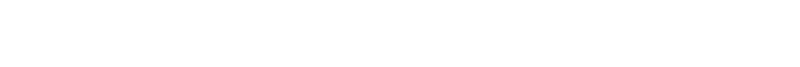

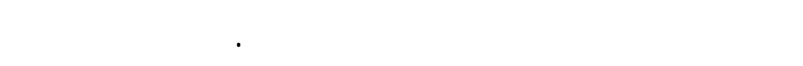
معلملات اللسماد الحيوى (PS) كانت مقفوقة لفن القيلست

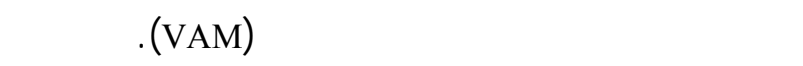

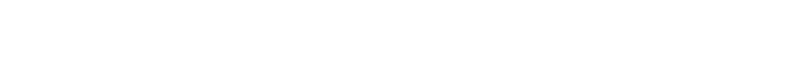

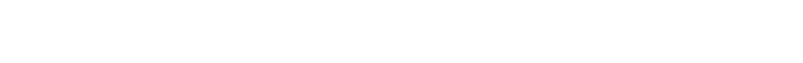
والبذور لنبت القرطم تصاعديا كالاق: $\mathrm{RP}_{2}+(\mathrm{AV})+\mathrm{FYM}_{1}<\mathrm{SP}_{2}+(\mathrm{AV})+\mathrm{FYM}_{1}<\mathrm{SP}_{2}+$ $(\mathrm{PS})+\mathrm{FYM}_{1}<\mathrm{SP}_{2}+(\mathrm{AV}+\mathrm{PS})+\mathrm{FYM}_{1}<\mathrm{SP}_{2}+$ $(\mathrm{AV}+\mathrm{PS})+\mathrm{FYM}_{2}$.

وقد أعطى التكلمل بين اللس مدة المعني ـة والحيوي ـة للفوسفورمع اضضافة المادة العضوية المعلملة اللثر ت أثيرً والق أدت اله الحصول على (SP $\left.2+\mathrm{VAM}+\mathrm{PS}+\mathrm{FYM}_{2}\right)$ اعلى محصول للقرطم حيث كلن 7,09 وךَ, باطن/ هكتار

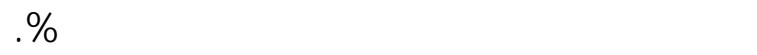

قيمت درلسة حقلية لنبت القرطم بمهط ـة رلسس در

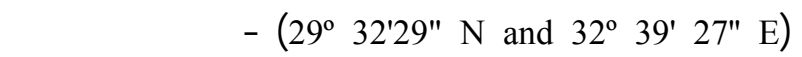

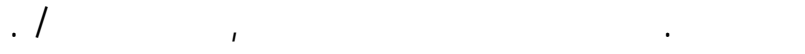

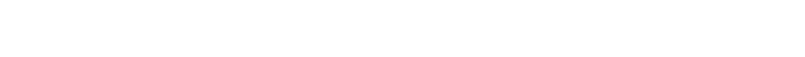

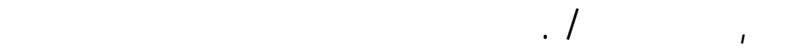

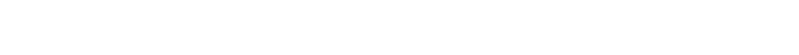

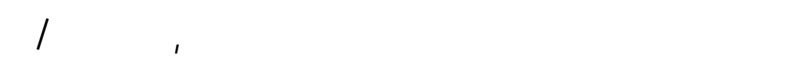

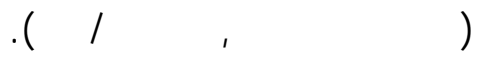
الهدف من الدرلسة هو تقيم تأثير ك لـ م ـن الت سميد

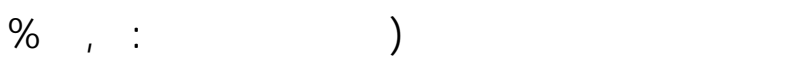

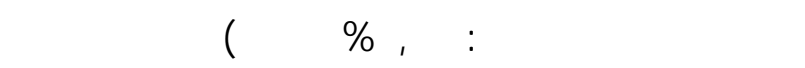
الحيوية المذيبة للفوسفور على انتلجية وجوة نباتلت القرطم النلمي فى أرض جيرية ملحية وعلى محتوى الزيت تحد تالت ظروف ملوحة ميل الرى والتربة فى رلسسدر -سيناء. توضح النتائج المتحصل عليها ان القيلست المحصولية وتركي -ز المغ خيت (نيت ـروجين، فوس فور، بوتلد ـيوم)

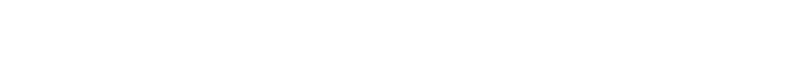

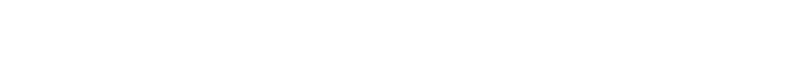
فوسفلت وصخر الفوسفلت مع اضض لفة الاسد مدة الحيوي ة 